Clinical Immunology

Title:

\title{
Lack of association of vitamin D receptor gene polymorphisms/haplotypes in Sjögren's syndrome
}

Running title: Vitamin D receptor polymorphisms in Sjögren's syndrome

Authors:

Erika Zilahi $^{1{ }^{* *}}$, Ji-Qing Chen ${ }^{1}$, Gábor Papp ${ }^{1}$, Antónia Szántó ${ }^{1}$, Margit Zeher ${ }^{1}$

${ }^{1}$ Department of Clinical Immunology, Department of Medicine, Medical Health Science

Centre, University of Debrecen

** Correspondence author:

Dr. Erika Zilahi

Department of Clinical Immunology, Department of Medicine, Medical Health Science Centre, University of Debrecen

Debrecen, Móricz Zs. krt. 22.

H-4032

Tel/Fax: 36+52/ 255-218

e-mail: ezilahi@gmail.com 


\begin{abstract}
The vitamin $\mathrm{D}$ is involved in a wide variety of biological processes including bone metabolism, modulation of the immune response, and regulation of cell proliferation and differentiation. Vitamin $\mathrm{D}$ has several immunomodulatory effects through vitamine D receptor (VDR). A series of common single nucleotide polymorphisms (SNPs) in the vitamin D receptor gene have been linked to numerous of diseases, including osteoarthritis, diabetes, cancer, cardiovascular diseases, tuberculosis, virus infections, urinary stones, periodontitis. Several studies have reported that genetic variations of VDR might be a risk factor for the development of autoimmune diseases such as systemic lupus erythematosus (SLE), multiple sclerosis (MS), psoriasis, autoimmune thyroid diseases (AITD). However no data is available on the possible relationship between primary Sjögren's syndrome and VDR gene polymorphisms. Our aim was to determine VDR gene BsmI, ApaI, TaqI and FokI polymorphism genotypes in pSS patients and healthy controls to analyze whether a relationship exists between polymorphisms in the VDR gene and susceptibility to Sjögren's syndrome. In the current study, 105 patients with pSS and 93 healthy controls were tested for VDR gene polymorphisms (BsmI, ApaI, TaqI and FokI) genotypes. There were no statistical differences in the distribution of BsmI, TaqI, ApaI and FokI genotypes and the common haplotypes between pSS patients and healthy controls. We hypothesized that the TaqI, BsmI, ApaI, and FokI polymorphisms of the VDR gene are not associated with the development of primary Sjögren's syndrome in the Hungarian population studied.
\end{abstract}

Keywords: SNP, Vitamin D receptor (VDR), Sjögren's syndrome, haplotypes 


\section{Introduction}

Primary Sjögren's syndrome is a common, slowly progressive systemic autoimmune inflammatory disease that primarily affects the salivary and lachrymal glands leading to dry mouth and dry eye diseases [1]. Besides the typical glandular symptoms (GS), other systemic symptoms, denoted as extraglandular manifestations (EGMs) can also be found in a subset of patients [2]. The pathogenesis of Sjögren's syndrome reveals a complex and heterogeneous array of diverse immunological, genetic and environmental phenotypes, making identification of the precise autoimmune mechanisms difficult to define. Numerous genes might have been linked to the emergence of Sjögren's syndrome [3] including vitamin D receptor (VDR) gene that synthesizes the receptor of vitamin D. VDR is an immunomodulator known to affect both innate and adaptive immune responses.

Vitamin D is essential for bone and mineral homeostasis and exhibits immunoregulatory and anti-inflammatory properties [4, 5]. Vitamin $\mathrm{D}$ regulates cell-mediated immunity by modulating interleukin-12 (IL-12) and IFN-gamma, suppressing lymphocyte proliferation, antibody production, and cytokine synthesis [6]. Vitamin D considered as a regulator of the immune system [4, 7]. Vitamin D mediates its multiple actions via binding to its receptor (VDR), which is a $48 \mathrm{kDa}$ soluble protein present on monocytes, and $\mathrm{T}$ and $\mathrm{B}$ lymphocytes [8].

The VDR gene encodes a ligand activated transcription factor which is located on chromosome 12 (12q12-q14), with numerous SNPs [9]. Some of the SNPs play a key role in the modification of the uptake of $1,25(\mathrm{OH})_{2} \mathrm{D}$. It has been considered that these SNPs may modify vitamin D function. Although VDR gene has more than 100 restriction endonuclease recognition sites, 4 of them are known polymorphisms: FokI (rs2228570), BsmI (rs1544410), ApaI (rs7975232), and TaqI (rs731236) [9-12]. FokI is located in exon 2. Three 
polymorphisms, BsmI and ApaI (both in intron 8), and TaqI (in exon 9) have been identified at the 3' end of the gene. Recent studies have reported that allelic variations of the VDR gene polymorphisms might be associated with a variety of diseases, including osteoarthritis, diabetes, cancer, cardiovascular diseases, tuberculosis, virus infections, urinary stones, periodontitis [13-18]. These findings suggest that allelic variations of the VDR gene may partially represent a genetic component associated with the development of autoimmune diseases. Several studies have reported that genetic variations of VDR might be a risk factor for the development of autoimmune diseases such as systemic lupus erythematosus (SLE), multiple sclerosis (MS), psoriasis, autoimmune thyroid diseases (AITD), type I diabetes (T1D) [19-25].

The VDR polymorphisms (BsmI, ApaI and TaqI) have been shown to be in strong linkage disequilibrium (LD) [9]. LD means the association (or co-occurrence) of alleles of adjacent polymorphisms with each other. LD in combination with one or more functional polymorphisms elsewhere in the VDR gene is believed to explain observed associations between the VDR gene and diseases.

In general, all polymorphisms start as mutations which occur perhaps due to a DNA damage incident, then can grow in the population and become true polymorphisms. Allele frequency differences between ethnic groups most likely result from evolutionary processes and population genetic behavior. The same holds true for the LD between the polymorphisms and haplotype structure. To illustrate this, Table 1 shows the frequencies of the BsmI-ApaI-TaqI haplotypes which Uitterlinden et al. [9] investigated in different ethnic groups. In general, most of the population studies of VDR gene were performed in Europeans and Asians and the results have been inconsistent. The results of VDR polymorphisms genotype studies show discrepancies in the different populations studied probably because of confounding factors related to ethnicity and environment. 
To our knowledge, there are no information in the literature about the VDR gene polymorphisms and their connection with Sjögren's syndrome. In our study, we determined VDR gene BsmI, ApaI, TaqI and FokI polymorphisms in pSS patients and healthy controls to analyze whether a relationship exists between polymorphisms/haplotypes in the VDR gene and susceptibility to Sjögren's syndrome. We also established haplotype analysis which recently became important due to the newly developed bioinformatics background.

\section{Materials and methods}

\section{Patients}

105 Sjögren's syndrome patients [53 with glandular symptoms (GS) and 52 with EGMs, mean age 59.4 years, range from 26 to 82 years old, 100 females and 5 males] were enrolled in the present study, recruited from the Autoimmune Outpatient Clinic of the Division of Clinical Immunology, Institute of Medicine, Medical and Health Science Center, University of Debrecen. The diagnosis of pSS was established according to the European-American consensus criteria. 93 healthy individuals (mean age 41.2 years, range from 14 to 70 years, 52 females and 41 males) taking no immunosuppressive or immunomodulating medications served as controls. Informed written consent was obtained from the subjects, and the study has been approved by the ethics committee of the University of Debrecen. All experiments carried out were incompliance with the Declaration of Helsinki.

Among patients with pSS, 52 had EMGs, whereas 53 had only glandular symptoms. The distribution of EMGs patients were as follows: polyarthritis $n=44$, Raynaud's phenomenon $n=18$, vasculitis $n=5$, polyneuropathy $n=5$, myositis $n=4$, thyreoiditis $n=5$, pulmonary fibrosis $\mathrm{n}=3$, primary biliary cirrhosis $\mathrm{n}=2$, renal tubular acidosis $\mathrm{n}=1$, pericarditis $\mathrm{n}=1$, antiphospholipid syndrome $n=1$, neck lymphadenopathy $n=1$, marginal zone $B$ cell lymphoma $\mathrm{n}=1$. 


\section{Sample handling}

Peripheral blood samples obtained from each study subject were collected.

\section{Genomic DNA Extraction}

High molecular weight DNA for genotyping was extracted from peripheral blood, which was collected in EDTA vacutainers. Genomic DNS was extracted according to the manufacturer's recommendation using a QiaAmp DNA Blood Mini Kit (Qiagen GmbH, Germany). DNA was quantitated by UV absorption at $260 \mathrm{~nm}$ and $280 \mathrm{~nm}$ and stored at $-20^{\circ} \mathrm{C}$ until analyzed.

\section{Genotyping}

\section{Genotyping of BsmI polymorphism (rs1544410)}

Genotyping of BsmI polymorphism was carried out in PCR-amplified genomic DNA by allelic discrimination using Taqman from Applied Biosystems (Foster City, CA, USA). PCR primers and TaqMan probes specific for the BsmI polymorphism were purchased from Applied Biosystems (Foster City, CA, USA). The assay enables scoring of both alleles in a single well. Real-time PCR was performed in Corbett Rotor-Gene RG-3000 equipment.

The PCR reaction was carried out in a $20 \mu 1$ reaction volume containing TaqMan Universal Master Mix (2X, 4331182, Applied Biosystems), TaqMan genotyping Assay (40X) and optimized quantities of genomic DNA. The Universal Master Mix contained AmpliTaq Gold DNA Polymerase, AmpErase UNG, dNTPs with dUTP, passive reference, and optimized buffer components. Reactions were set up in duplicate. Thermal cycling was initiated by incubation at $95^{\circ} \mathrm{C}$ for $10 \mathrm{~min}$ for optimal AmpErase UNG activity and activation of Amplitaq Gold DNS polymerase. After this initial step, 40 cycles of PCR were performed. Each PCR cycle consisted of heating to $92^{\circ} \mathrm{C}$ for $15 \mathrm{sec}$ for melting, and to $60^{\circ} \mathrm{C}$ for $1 \mathrm{~min}$ for annealing and extension. 


\section{Genotyping of FokI, ApaI and TaqI polymorphisms}

The genotype for FokI, ApaI, and TaqI polymorphisms of the VDR gene was determined by the digestion pattern of the amplified DNA fragment using the restriction enzymes FokI, ApaI, and TaqI.

\section{FokI polymorphism (rs2228570)}

Genotypes for the FokI polymorphisms were studied by PCR using appropriate primers as follows: 5' -AGC TGG CCC TGG CAC TGA CTC TGC TCT 3-' and 5' -ATG GAA ACA CCT TGC TTC TTC TCC CTC- 3' [26]. PCR products were amplified in a programmable thermal cycler (Eppendorf-MC-EP model). The PCR conditions were $10 \mathrm{~min}$ at $95^{\circ} \mathrm{C}$ for initial denaturation, $30 \mathrm{sec}$ at $95^{\circ} \mathrm{C}, 30 \mathrm{sec}$ at $70^{\circ} \mathrm{C}, 30 \mathrm{sec}$ at $72^{\circ} \mathrm{C}, 40 \mathrm{cycles}$, followed by 5 min at $72{ }^{\circ} \mathrm{C}$ for final extension. The specific PCR products were obtained $265 \mathrm{bp}$. The amplified products were digested with FokI (Fermentas Life Sciences) for 1 hour at $37^{\circ} \mathrm{C}$ according to the manufacturer's instructions, and electrophoresed on 3\% agarose gel and visualized by SYBR Green I staining (Figure 1). FokI genotypes were defined by capital letters in the absence of the restriction site (allele-F) and small letters where the restriction site was present (allele-f) (Figure 1).

\section{ApaI and TaqI polymorphisms (rs7975232 and rs731236)}

For the genotypes for ApaI and TaqI polymorphism the following specific primers 5' -CAG AGC ATG GAC AGG GAG CAA G- 3' and 5' -GCA ACT CCT CAT GGC TGA GGT CTC A- 3' were used by PCR as previously described [27]. The running conditions were: predenaturation at $94{ }^{\circ} \mathrm{C}$ for $4 \mathrm{~min}$, followed by 40 cycles of denaturation at $94{ }^{\circ} \mathrm{C}$ for $30 \mathrm{sec}$, annealing at $70{ }^{\circ} \mathrm{C}$ for $1 \mathrm{~min}$, and extension at $72{ }^{\circ} \mathrm{C}$ for $1 \mathrm{~min}$. Finally, extension was carried out at $72{ }^{\circ} \mathrm{C}$ for $4 \mathrm{~min}$. Specific PCR products were obtained $740 \mathrm{bp}$. The PCR products were 
digested with ApaI (Fermentas Life Sciences) for 4 hours at $37{ }^{\circ} \mathrm{C}$ and TaqI (Fermentas Life Science) for 1 hour at $60{ }^{\circ} \mathrm{C}$. After digestion the fragments were separated by electrophoresis in $3 \%$ agarose gels and visualized by SYBR Green I staining (Figure 1). For both ApaI and TaqI genotypes were defined by capital letters in the absence of the restriction site $(\mathrm{A}, \mathrm{T}$, respectively) and small letters where the restriction site was present (a, $\mathrm{t}$, respectively).

\section{Statistical analysis}

Genotype frequencies were calculated by direct counting. Allele frequencies were calculated from genotype frequencies based upon Hardy-Weinberg equilibrium. For comparisons of mean values between patients and controls statistical analysis was performed by the independent samples t-test. Differences in genotypic and allelic distribution of VDR polymorphisms between patients and controls were determined by Pearson Chi-square $\left(\chi^{2}\right)$ test using SPSS 20.0 statistical software. The $P$ value less than 0.05 was regarded as statistically significant.

Haplotype analysis was done by CHAPLIN 1.2 software. The possible haplotypes including genetic variants of three VDR polymorphisms (BsmI, ApaI and TaqI) and four polymorphisms studied (FokI, BsmI, ApaI, and TaqI) in Table 3 and Figure 2.

Pairwise linkage disequilibrium (LD) between the VDR gene polymorphisms was computed, and LD plots were constructed by Haploview software version 4.2 [28].

\section{Results}

We studied VDR-BsmI, VDR-ApaI, VDR-TaqI and VDR-FokI polymorphisms in 105 pSS patients and 93 healthy controls. Genotype analysis of the VDR gene FokI, BsmI, ApaI and TaqI polymorphisms did not show a significant deviation from Hardy-Weinberg equilibrium in the pSS patients and control groups. 


\section{Allele frequencies of VDR gene polymorphisms in pSS patients}

The distribution of allelic frequencies for the four polymorphisms studied here is summarized in Table 2. The characteristics are shown separately for GS patients and EGMs patients, respectively. No significant difference was found in allele frequencies when data were compared between pSS cases and control individuals (Table 2). No significant difference was observed when the pSS cases were grouped into GS cases and EGMs cases (Table 2).

\section{Genotype frequencies of VDR gene polymorphisms in pSS patients}

No significant difference was found in the genotype frequencies when the VDR gene polymorphisms genotypes of pSS patients and healthy individuals were compared (Table 2). The same result has been confirmed between GS cases and EGMs cases (Table 2). However we recognized slightly increased prevalence of the Aa genotype in EGMs patients compared with GS patients, $57.69 \%$ and $39.62 \%$, respectively. Likewise, we also found a mild increased prevalence of the Tt genotype in EGMs patients compared with GS group and healthy group, $53.85 \%, 41.51 \%$ and $39.79 \%$, respectively. These differences have not been proven significant. Genotype frequencies of VDR gene polymorphisms did not differ between pSS cases and controls in any comparison performed (Table 2).

\section{Linkage disequilibrium and haplotype frequencies of VDR gene polymorphisms in pSS groups}

The haplotypes might provide valuable data where genotypes alone unable to do. The haplotype frequencies among the VDR-FokI, VDR-BsmI, VDR-ApaI and VDR-TaqI polymorphisms in both the patients with Sjögren's syndrome and the healthy controls were evaluated by CHAPLIN 1.2 software. 
The estimated haplotype frequencies for VDR-BsmI, VDR-ApaI and VDR-TaqI polymorphisms of the Sjögren's syndrome patients and control individuals are shown in Table 3. The baT and $B A t$ haplotypes were found the most frequent haplotypes in both the patient group (51\% and 33\%) and the control group (48\% and 31\%). These three-marker haplotype alleles were identified as the most frequent and corresponded haplotypes by Morrison et al. [10] as well. Similarly, haplotype 1 baT (43\%); and haplotype $2 B A t(39 \%)$ were also found the most frequent haplotypes by Utterlinden et al. [9] in a large Caucasian population (Table 1). The BaT haplotype was present neither in patients nor in the controls. Three haplotypes (BAT, Bat and $b A t)$ were relatively uncommon (frequency < $10 \%$ ) either in the patient group or in the control group.

The distribution of the frequency of four-marker haplotype alleles (VDR-FokI, VDR-BsmI, VDR-ApaI, and VDR-TaqI) in Sjögren's syndrome cases and controls are shown in Figure 2. According to the four-marker haplotype prevalence, frequencies of the sixteen possible haplotypes do not show significant differences between the patient and the control group (Figure 2). The most common estimated haplotype was FbaT both in the patient and the control group (frequencies are $29.63 \%$ and $29.78 \%$, respectively). The FBAt and fbaT haplotypes showed similar haplotype frequency when the patients and the controls data were compared $(16.19 \%$ and $22.59 \% ; 19.79 \%$ and $24.05 \%$, respectively). Some of the possible haplotypes ( $F B a T, f B A T, f B a T$, $f b A t$, and $f b a t)$ were not present neither in patients nor in the control group estimated.

Pairwise LD was computed and LD plots were constructed using the Haploview software version 4.2. $\mathrm{LD}$ analysis revealed a very strong $\mathrm{LD}\left(\mathrm{r}^{2}>0.8\right)$ between ApaI and TaqI polymorphisms, a strong LD ( $\mathrm{r}^{2}$ between 0.67 and 0.7$)$ between BsmI and ApaI or BsmI and TaqI polymorphisms, and a very weak LD $\left(r^{2}<0.3\right)$ was observed between FokI and other polymorphisms in the control group. In patients, very strong $\left(r^{2}>0.8\right)$ to moderate $\left(r^{2}=0.67\right.$ - 
0.7) LD was found between BsmI and ApaI, TaqI polymorphisms, ApaI and TaqI polymorphisms (Figure 3). No LD was observed between FokI and other polymorphisms in patients.

\section{Discussion}

The VDR gene polymorphisms have been identified and analyzed so far in a wide variety of diseases, including osteoarthritis, diabetes, cancer, cardiovascular diseases, tuberculosis, virus infections, urinary stones, periodontitis and autoimmune diseases. Several studies have reported that genetic variations of VDR might be associated with the development of autoimmune diseases such as systemic lupus erythematosus (SLE), multiple sclerosis (MS), psoriasis, autoimmune thyroid diseases (AITD). In our best knowledge, the possible relationship between primary Sjögren's syndrome and VDR gene polymorphisms has not been investigated up to now. In the current study, our aim was to determine VDR gene FokI, BsmI, ApaI and TaqI genotypes in pSS patients and healthy controls. As the results of our investigations there were no statistical differences of the FokI (FF, Ff, ff), BsmI (BB,Bb, bb), ApaI (AA, Aa, aa), and TaqI (TT, Tt, tt) genotypes and allelic frequencies between Sjögren's syndrome patients and control individuals. Besides of these findings the haplotypes frequencies among the VDR-FokI, VDR-BsmI, VDR-ApaI and VDR-TaqI polymorphisms in both the patients with Sjögren's syndrome and healthy controls were evaluated and showed nearly the same distribution. Analysis of FokI, BsmI, ApaI, and TaqI locus haplotype frequencies failed to show any association in the study groups, suggesting that FokI, BsmI, ApaI, and TaqI polymorphisms of VDR gene are not associated with the development of Sjögren's syndrome in the Hungarian population studied. We conclude that the VDR gene polymorphisms do not seem to be a candidate genetic marker for Sjögren's syndrome according to our study which is the first study to investigate all the four polymorphisms of 
VDR gene in patients with Sjögren's syndrome. The baT haplotype was found as the most frequent haplotype (Table 3) in the patient group and the control group. Table 2 shows the frequencies of the BsmI-ApaI-taqI haplotypes of VDR gene which Uitterlinden et al. [9] investigated in different ethnic groups. According to Table 2, the distribution of the most frequent haplotype (baT) was different among Caucasians, Asians and Africans, 43\%, 75\% and $26 \%$, respectively. We calculated slightly higher frequency for the baT haplotype in the patient group and the control group, $51 \%$ and $48 \%$, respectively. Despite of Caucasian origin of our study subjects, a slightly elevated distribution of the baT haplotype might be explained by the population genetic behavior. Haplotype frequencies of VDR gene may vary within Caucasian population as well as the strength of the LD between different VDR polymorphisms.

Alterations in VDR gene expression and VDR protein activity could lead to deregulation of vitamin D uptake, metabolism, and serum levels of the biologically active vitamin $\mathrm{D}$. Furthermore, certain polymorphisms of the VDR gene may have regulatory effects on vitamin D function and metabolism [25].

Szodoray et al. [29] recently reported that the vitamin D levels were found similar in both the overall pSS patients and controls in the Hungarian population they studied. Similarly, no significant differences were found in vitamin D levels of the blood in patients with and without EGMs [29]. Allele frequencies we have found for VDR-FokI, VDR-BsmI, VDRApaI, and VDR-TaqI in pSS patients might help to explain the correlation between the genotypes of VDR gene of pSS patients and normal blood level of vitamin D in patients examined previously [29].

\section{Conclusion}


This is the first study to investigate all the four polymorphisms of VDR gene in patients with Sjögren's syndrome. There were no statistical differences of the FokI (FF, Ff, ff), BsmI (BB,Bb, bb), ApaI (AA, Aa, aa), and TaqI (TT, Tt, tt) genotypes and allelic frequencies between Sjögren's syndrome patients and control individuals. Analysis of FokI, BsmI, ApaI, and TaqI locus haplotype frequencies also failed to show any association in the study groups. This study suggests that FokI, BsmI, ApaI, and TaqI polymorphisms of VDR gene are not associated with the development of Sjögren's syndrome in the Hungarian population studied. The VDR gene polymorphisms do not seem to be a candidate genetic marker for Sjögren's syndrome.

\section{Acknowledgments}

This work was supported by Grant No. K101470 from the Hungarian National Scientific Research Fund (OTKA) and TÁMOP-4.2.2.A-11/1/KONV-2012-0023 project. This project is co-financed by the European Union and European Social Fund.

The authors thank for the excellent technical helps from Andrea Nagy and Katalin Deak.

\section{Competing interest}

The authors declare that there are no conflicts of interests.

\section{Authors' contributions}

EZ designed all the experiments and performed some experiments, analyzed data, and wrote the manuscript, QJC performed research experiments, GP collected and analyzed patients data, ASZ collected data, MZ reviewed the manuscript, provided suggestions to the research. All authors read and approved the final manuscript. 


\section{References}

1. Zeher M. Sjögren's syndrome. In Sjögren's syndrome and associated disorders. Edited by Zeher M., Szodoray P. Kerala, India: Transworld Research Network, 2009:1-25.

2. Jonsson R, Moen K, Vestrheim D, Szodoray P. Current issues in Sjögren's syndrome. Oral Dis 2002;83:130-140.

3. Centola M, Frank MB, Bolstad AI, et al.Genome-scale assessment of molecular pathology in systemic autoimmune disease using microarray technology: a potential breakthrough diagnostic and induvidualized therapy-desig tool. Scand J Immunol 2006;64:236-242.

4. DeLuca HF. Overview of general physiologic features and functions of vitamin D. Am J Clin Nutr 2004;80:16895-965.

5. van Etten E, Mathieu C. Immunoregulation by 1,25-dihydroxivitamin D3: basic concept. J Steroid Biochem Mol Biol 2005;97:93-101.

6. Penna D, Adorini L. Alpha, 25-dyhidroxivitamin D3 inhibits differentiation, maturation, activation, and survival of dendritic cells leading to impaired alloreactive T cell activation. J Immunol 2000;164:2405-11.

7. Cantorna MT. Mechanism of vitamin D on the immune system. Proc Nutr Soc 2010;69:286-289.

8. Arnson Y, Amital H, Shoenfeld Y. Vitamin D and autoimmunity: new aetiological and therapeutic consideration. Ann Rheum Dis 2007;66:1137-1142.

9. Uitterlinden AG, Fang Y, Van Meurs JB, Pols HA, Van Leeuwen JP. Genetics and biology of vitamin D receptor polymorphisms. Gene 2004;338:143-156. 
10. Morrison NA, Qi JC, Tokita A, Kelly PJ, Crofts L, Nguyen TV. Prediction of bone density from vitamin D receptor alleles. Nature 1994;367:284-287.

11. Morrison NA, Yeoman R, Kelly PJ, Eisman JA. Contribution of trans-acting factor alleles to normal physiologycal variability:vitamin D receptor gene polymorphisms and circulating osteocalcin. Proc Natl Acad Sci 1992;89:6665-6669.

12. Faraco JH, Morrison NA, Baker A, Shine J, Frossard PM. ApaI polymorphism at the human vitamin D receptor gene locus. Nucleic Acids Res 1989;17:2150.

13. Mishra DK, Wu Y, Sarkissyan H. Vitamin D receptor gene polymorphisms and prognosis of breast cancer among African-American and Hispanic women. PLOS $2013 ; 8$.

14. Hirvonen A, Watson M, Pittman G, Mohler JL, Bell DA. Association of prostate cancer with vitamin D receptor gene polymorphism. Cancer Research 1996;56:4108-4110.

15. Vidal C, Grima C, Brincat M, Megally N, Xuereb-Anastasi A. Associations of polymorphisms in the vitamin D receptor gene (BsmI and FokI) with bone mineral density in postmenopausal women in Malta. Osteoporos Int 2003;14:923-928.

16. Andraos C, Koorsen G, Knight JC, Bornman L. Vitamin D receptor gene methylation is associated with ethnicity, tuberculosis, and Tai polymorphism. Human Immunology 2011;72:262-8.

17. Seo IY, Kang IH, Chae SC, Park SC, Lee YJ, Yang YS. Vitamin D receptor gene AlwI, FokI, ApaI, and TaqI polymorphisms in patients with urinary stone. J. Urology 2010;75:923-927.

18. Alagarasu K, Honap T, Mulay AP, Bachal RV, Shah PS, Cecilia D. Association of vitamin D receptor gene polymorphisms with clinical outcomes. Hum Immunol 2012;73:1194-1199. 
19. Feng M, Li H, Chen SF, Li WF, Zhang FB. Polymorphisms in the vitamin D receptor gene and risk of autoimmune thyroid diseases: a meta-analysis. Endocrine 2013;43:318326.

20. Lee YH, Lee HS, Choi SJ, Ji JD, Song GG. Association between vitamin D receptor polymorphisms and susceptibility to rheumatoid arthritis and systemic lupus erythematosus: a meta-analysis. Mol Biol Rep 2012;39:3643-51.

21. Acikbas I, Sanli B, Tepeli E, Ergin S, Aktan S, Bagci H. Vitamin D receptor gene polymorphisms and haplotypes (ApaI, BsmI, FokI, TaqI) in Turkish psoriasis patients. Med Sci Monit 2012;18:661-666.

22. Mostowska A, Lianeri M, Wudarski M, Olesinska M, Jagodzinski PP. Vitamin D receptor gene BsmI, FokI, ApaI and TaqI polymorphisms and the risk of systemic lupus erythematosus. Mol Biol Rep 2013;40:803-810.

23. Sioka C, Papakonstantinou S, Markoula S, Gkartziou F, Georgion A, Georgion I, et al. Vitamin D receptor gene polymorphisms in multiple sclerosis patients in northwest Greece. J Negat Results BioMed 2011;10:3.

24. Rass P, Pákozdi A, Lakatos P, Zilahi E, Sipka S, Szegedi G, et al. Vitamin D receptor gene polymorphism in rheumatoid arthritis and associated osteoporosis. Pheumatol Int 2006;26:964-971.

25. Monticielo OA, Teixeira Tde M, Chies JA, Brenol JC, Xavier RM. Vitamin D and polymorphisms of VDR gene in patients with systemic lupus erythematosus. Clin Rheumatol 2012;31:1411-1421.

26. Harris SS, Eccleshall TR, Gross C, Dawson-Hughes B, Feldman D. The vitamin D receptor start codon polymorphism (FokI) and bone mineral density in premenopausal American black and white women. J Bone Miner Res 1997;12:1043-48. 
27. Riggs BL, Nguyen TV, Melton LJ, Morrison NA, O1Fallon WM, Kelly PJ, et al. The contribution of vitamin D receptor gene alleles to the determination of bone mineral density in normal and osteoporotic women. J. Bone Miner Res 1995; 10:991-995.

28. Linkage Disequilibrium analysis. http://www.broad.mit.edu/mpg/haploview. [Online]

29. Szodoray P, Horváth IF, Papp G, Baráth S, Gyimesi E, Csathy L, et al. The immunoregulatory role of vitamins A, D and E in patients with primary Sjögren's syndrome. Rheumatology 2010;49:211-217. 


\section{Tables}

\begin{tabular}{|c|c|c|c|}
\hline & \multicolumn{3}{|c|}{ Ethnic group (\%) } \\
\hline BsmI-ApaI-TaqI haplotypes & Caucasian & Asian & 26 \\
\hline baT & 43 & 75 & 16 \\
\hline BAt & 39 & 7 & 59 \\
\hline bAT & 11 & 17 & African \\
\hline
\end{tabular}

Table 1. Comparison of BsmI-ApaI-TaqI haplotypes across the three major ethnic groups.

Data are from Uitterlinden et al. 1994. (9) 


\begin{tabular}{|c|c|c|c|c|}
\hline Enzyme analysis & $\begin{array}{l}\text { Sjögren's } \\
\text { syndrome patients }\end{array}$ & $\begin{array}{l}\text { Sjögren's } \\
\text { syndrome patients } \\
\text { with EGMs }\end{array}$ & $\begin{array}{l}\text { Sjögren's } \\
\text { syndrome patients } \\
\text { with GS }\end{array}$ & Controls \\
\hline BsmI polymorphism & $\mathrm{p}=0.6791$ & $\mathrm{p}=0.3966$ & $\mathrm{p}=0.5868$ & \\
\hline \multicolumn{5}{|l|}{ Genotypes } \\
\hline BB & $12.60 \%$ & $9.60 \%$ & $13.46 \%$ & $15.90 \%$ \\
\hline Bb & $47.41 \%$ & $55.70 \%$ & $40.38 \%$ & $46.20 \%$ \\
\hline bb & $40.51 \%$ & $34.60 \%$ & $46.15 \%$ & $37.80 \%$ \\
\hline \multicolumn{5}{|l|}{ Allele frequencies } \\
\hline B & 0.64 & 0.63 & 0.66 & 0.61 \\
\hline $\mathbf{b}$ & 0.34 & 0.37 & 0.34 & 0.39 \\
\hline ApaI polymorphism & $\mathrm{p}=0.5331$ & $\mathrm{p}=0.5045$ & $\mathrm{p}=0.2804$ & \\
\hline \multicolumn{5}{|l|}{ Genotypes } \\
\hline $\mathbf{A A}$ & $20.00 \%$ & $17.31 \%$ & $22.64 \%$ & $24.73 \%$ \\
\hline Aa & $48.57 \%$ & $57.69 \%$ & $39.62 \%$ & $50.54 \%$ \\
\hline aa & $31.43 \%$ & $25.00 \%$ & $37.74 \%$ & $24.73 \%$ \\
\hline \multicolumn{5}{|l|}{ Allele frequencies } \\
\hline A & 0.44 & 0.46 & 0.42 & 0.5 \\
\hline $\mathbf{a}$ & 0.56 & 0.54 & 0.58 & 0.5 \\
\hline TaqI polymorphism & $\mathrm{p}=0.5905$ & $\mathrm{p}=0.2959$ & $\mathrm{p}=0.2804$ & \\
\hline \multicolumn{5}{|l|}{ Genotypes } \\
\hline TT & $37.14 \%$ & $32.69 \%$ & $41.51 \%$ & $40.86 \%$ \\
\hline $\mathbf{T t}$ & $47.62 \%$ & $53.85 \%$ & $41.51 \%$ & $39.79 \%$ \\
\hline tt & $15.24 \%$ & $13.46 \%$ & 16.98 & $19.35 \%$ \\
\hline \multicolumn{5}{|l|}{ Allele frequencies } \\
\hline $\mathbf{T}$ & 0.61 & 0.6 & 0.62 & 0.61 \\
\hline $\mathbf{t}$ & 0.39 & 0.4 & 0.38 & 0.39 \\
\hline FokI polymorphism & $\mathrm{p}=0.6133$ & $\mathrm{p}=0.7033$ & $\mathrm{p}=0.6061$ & \\
\hline \multicolumn{5}{|l|}{ Genotypes } \\
\hline FF & $34.28 \%$ & $34.62 \%$ & $33.96 \%$ & $42.25 \%$ \\
\hline Ff & $47.62 \%$ & $50.00 \%$ & $45.28 \%$ & $43.66 \%$ \\
\hline ff & $18.10 \%$ & $15.38 \%$ & $20.76 \%$ & $14.08 \%$ \\
\hline \multicolumn{5}{|l|}{ Allele frequencies } \\
\hline F & 0.58 & 0.6 & 0.57 & 0.64 \\
\hline f & 0.42 & 0.4 & 0.43 & 0.36 \\
\hline
\end{tabular}

Table 2. Distribution of VDR-FokI, VDR-BsmI, VDR-TaqI and VDR-ApaI genotypes in our Hungarian cases and controls. 


\begin{tabular}{|l|c|c|c|c|c|}
\hline \multirow{2}{*}{$\begin{array}{c}\text { Three-marker } \\
\text { haplotype }\end{array}$} & \multicolumn{3}{|c|}{ Haplotype } & \multicolumn{2}{c|}{ Frequency (\%) } \\
\cline { 2 - 6 } & BsmI & ApaI & TaqI & $\begin{array}{c}\text { Sjögren's } \\
\text { syndrome } \\
\text { patients }\end{array}$ & $\begin{array}{c}\text { Healthy } \\
\text { individuals }\end{array}$ \\
\hline baT & $\mathrm{b}$ & $\mathrm{a}$ & $\mathrm{T}$ & 51.52 & 48.35 \\
\hline BAt & $\mathrm{B}$ & $\mathrm{A}$ & $\mathrm{t}$ & 33.59 & 31.46 \\
\hline bAT & $\mathrm{b}$ & $\mathrm{A}$ & $\mathrm{T}$ & 9.16 & 10.16 \\
\hline BAT & $\mathrm{B}$ & $\mathrm{A}$ & $\mathrm{T}$ & 2.31 & 1.02 \\
\hline bat & $\mathrm{b}$ & $\mathrm{a}$ & $\mathrm{t}$ & 1.87 & 4.16 \\
\hline bAt & $\mathrm{b}$ & $\mathrm{A}$ & $\mathrm{t}$ & 1.55 & 1.69 \\
\hline Bat & $\mathrm{B}$ & $\mathrm{a}$ & $\mathrm{t}$ & 0 & 3.16 \\
\hline BaT & $\mathrm{B}$ & $\mathrm{a}$ & $\mathrm{T}$ & 0 & 0 \\
\hline
\end{tabular}

Table 3. Estimated haplotype frequencies among the VDR-BsmI, VDR-ApaI and VDR-TaqI polymorphisms in patients and controls. 


\section{Figure legends}

Figure 1. Genotyping for the FokI, ApaI, and TaqI VDR polymorphisms. The PCR products were digested with FokI, ApaI and TaqI digestion of the amplified region of the VDR gene producing different fragments leading to specific genotypes. The absence and/or presence of the enzyme recognition site were identified by SYBR Green I staining of fragments separated in a $3 \%$ agarose gel. Genotypes were assigned as FF, Ff and ff for the VDR-FokI polymorphisms, AA, Aa and aa for the ApaI polymorphisms, TT, Tt and tt for the TaqI polymorphisms.

Figure 2. Four-marker (FokI, BsmI, ApaI and TaqI polymorphisms) haplotype estimated prevalence (\%) in Sjögren's syndrome patients and healthy individuals.

Figure 3. Four common gene polymorphisms and pattern of linkage disequilibrium (LD) of $V D R$ gene of Sjögren's syndrome patients (A) and the healthy controls (B). Graphical presentation of the VDR gene with the location of polymorphisms studied. Numbers in the boxes represent the correlation coefficient value of $\operatorname{LD}\left(\mathrm{r}^{2}\right)$ value multiplied by 100 . The intensity of the dark color of the boxes represents strength of linkage disequilibrium $\left(\mathrm{r}^{2}\right)$ with dark boxes having high LD and white boxes having low LD. 


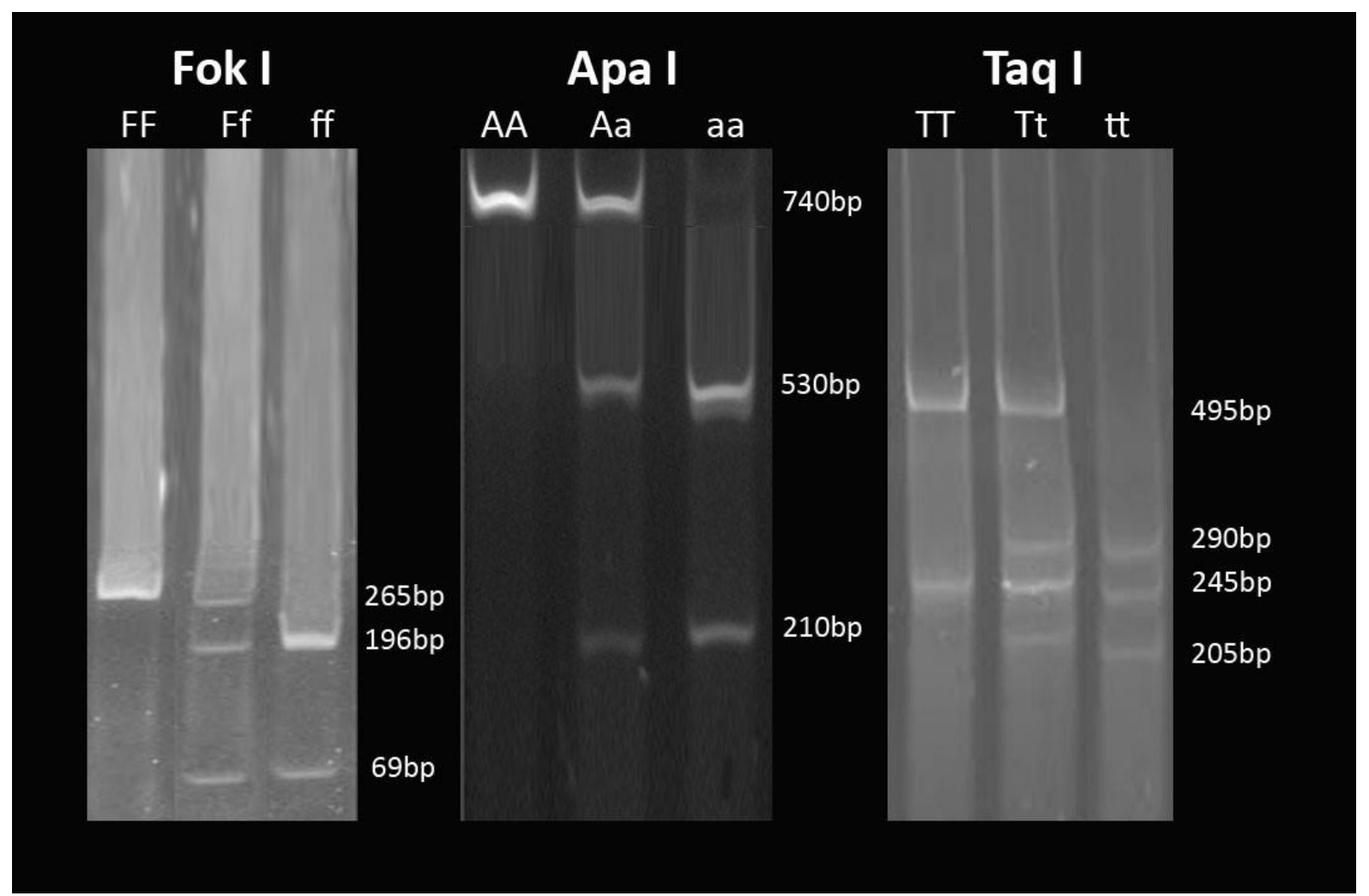

Figure 1. Genotyping for the FokI, ApaI, and TaqI VDR polymorphisms. The PCR products were digested with FokI, ApaI and TaqI digestion of the amplified region of the VDR gene producing different fragments leading to specific genotypes. The absence and/or presence of the enzyme recognition site were identified by SYBR Green I staining of fragments separated in a $3 \%$ agarose gel. Genotypes were assigned as FF, Ff and ff for the VDR-FokI polymorphisms, AA, Aa and aa for the ApaI polymorphisms, TT, Tt and tt for the TaqI polymorphisms. 


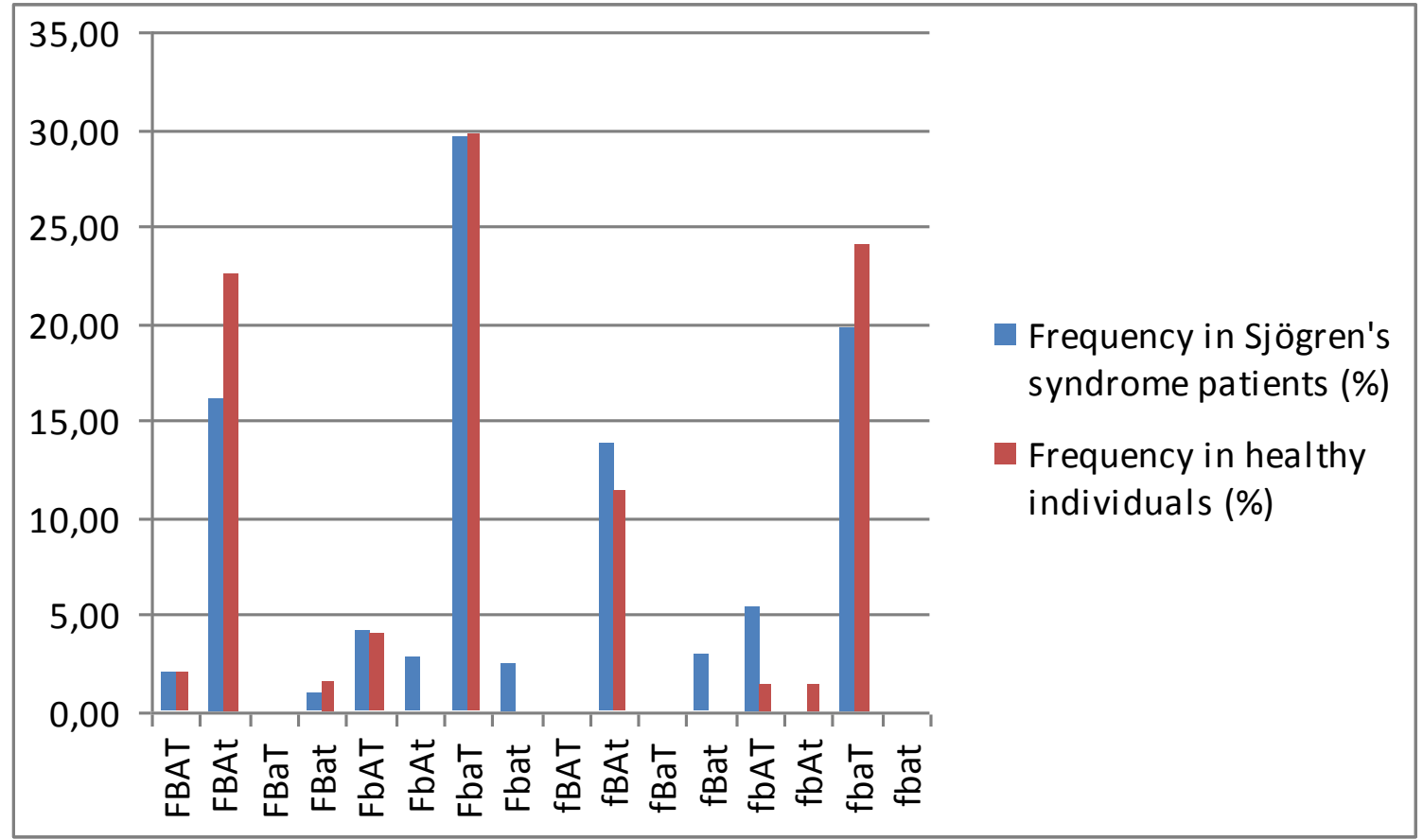

Figure 2. Four-marker (FokI, BsmI, ApaI and TaqI polymorphisms) haplotype estimated prevalence (\%) in Sjögren's syndrome patients and healthy individuals. 

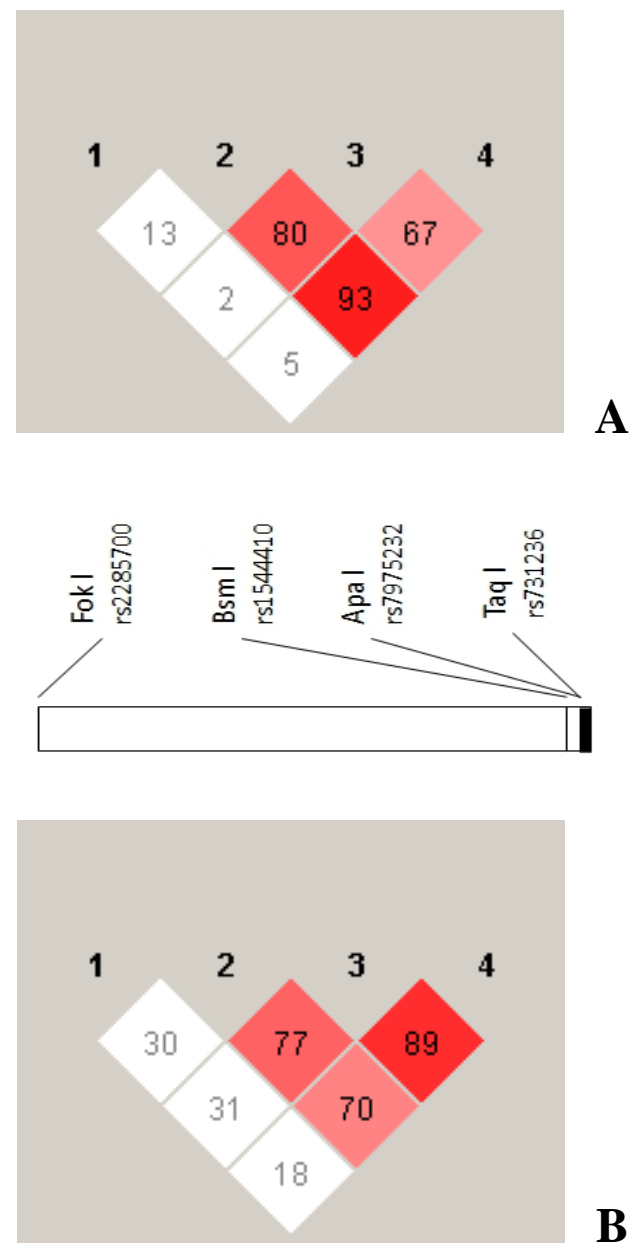

Figure 3. Four common gene polymorphisms and pattern of linkage disequilibrium (LD) of $V D R$ gene of Sjögren's syndrome patients (A) and the healthy controls (B). Graphical presentation of the VDR gene with the location of polymorphisms studied. Numbers in the boxes represent the correlation coefficient value of $\operatorname{LD}\left(\mathrm{r}^{2}\right)$ value multiplied by 100 . The intensity of the dark color of the boxes represents strength of linkage disequilibrium $\left(\mathrm{r}^{2}\right)$ with dark boxes having high LD and white boxes having low LD. 